\title{
Haemonchus contortus resistance to monepantel in sheep: fecal egg count reduction tests and randomized controlled trials
}

\section{Resistência de Haemonchus contortus ao monepantel em ovinos: testes de eficácia através de redução de contagem de ovos e controlado randomizado}

\author{
Aline Carvalho Martins ${ }^{1}$; Paula Luzia Formigoni Bergamasco²; Gustavo \\ Felippelli; José Hairton Tebaldi4; Marcela Figueredo Duarte Moraes ${ }^{3}$; Alan \\ Jonathan Pereira Testi ${ }^{5}$; Ivan Moura Lapera ${ }^{3}$; Estevam Guilherme Lux Hoppe ${ }^{6 *}$
}

\begin{abstract}
Worm infections are a major cause of economic losses in sheep farming, and their control depends essentially on anthelmintic drugs. After decades without the discovery of new drug types, a new class of anthelmintics, called aminoacetonitrile derivatives, represented by monepantel, was released on the market. In order to evaluate a report of low efficacy of monepantel on a sheep farm in the municipality of Taiúva, state of São Paulo, Brazil, fecal egg count reduction and critical tests were performed on a Haemonchus contortus strain collected from this farm. To this end, ten animals were experimentally infected with $5000 \mathrm{H}$. contortus third-stage larvae, and these animals were divided into two groups, control and treated, according to the treatment with monepantel. The parameters evaluated were reduction in fecal egg counts on post-treatment days (PTD) 0,2, 4, 7 and 14, and the therapeutic efficacy at the end of this period. Egg count reduction was observed starting on PTD 2, with a maximum reduction of $32.89 \%$ recorded on PTD 14 . The critical test revealed $24.65 \%$ efficacy, indicating resistance to the active ingredient monepantel. The ineffectiveness of monepantel may be associated with the excessive use of the anthelmintic, which the farmer administered at intervals of less than one month, without technical guidance or a defined criterion. Given that the anthelmintic was used on this farm for less than one year, according to the farmer, it can be inferred that $H$. contortus develops resistance to monepantel in a few generations if the product is used incorrectly.
\end{abstract}

Key words: Efficacy. Anthelmintic. Amino acetonitrile derivatives. Sheep.

\footnotetext{
${ }^{1}$ Discente do Curso de Doutorado do Programa de Pós-Graduação em Medicina Veterinária, Universidade Estadual Paulista, UNESP, Faculdade de Ciências Agrárias e Veterinárias, FCAV, Jaboticabal, SP; Prof., Universidade do Rio Verde, Rio Verde, GO, Brasil. E-mail: alinecarvalhomartins@hotmail.com

2 Aprimoranda de Clínica Médica dos Animais de Produção do Programa de Aprimoramento Profissional em Medicina Veterinária, UNESP, FCAV, Jaboticabal, SP, Brasil. E-mail: paulabergamasco2009@hotmail.com

${ }_{3}$ Discentes do Curso de Doutorado do Programa de Pós-Graduação em Medicina Veterinária, UNESP, FCAV, Jaboticabal, SP, Brasil. E-mail: gusvetfelippelli@gmail.com; ivanlapera@yahoo.com.br; marcelafdm@hotmail.com

4 Técnico de Laboratório, Departamento de Medicina Veterinária Preventiva e Reprodução Animal, UNESP, FCAV, Jaboticabal, SP, Brasil. E-mail: tebaldi@fcav.unesp.br

${ }^{5}$ Discente do Curso de Mestrado do Programa de Pós-Graduação em Medicina Veterinária, UNESP, FCAV, Jaboticabal, SP, Brasil. E-mail: alan_vet07@yahoo.com.br

${ }^{6}$ Prof. Dr., Departamento de Medicina Veterinária Preventiva e Reprodução Animal, UNESP, FCAV, Jaboticabal, SP, Brasil. E-mail: hoppe@fcav.unesp.br; e.hoppe@gmail.com

* Author for correspondence
} 


\title{
Resumo
}

\begin{abstract}
Verminoses são uma das principais causas de prejuízo econômico na ovinocultura, cujo controle depende essencialmente de fármacos anti-helmínticos. Depois de décadas sem o surgimento de novos grupos químicos de fármacos, uma nova classe de anti-helmínticos, os derivados da aminoacetonitrila, representados pelo monepantel, foram lançados no mercado. Com o objetivo de avaliar um relato de baixa eficácia do monepantel em uma propriedade produtora de ovinos do município de Taiúva, estado de São Paulo, foi realizado um teste de redução de contagem de ovos e um teste crítico em uma linhagem de Haemonchus contortus obtida da propriedade. Dez animais foram infectados experimentalmente com 5000 larvas de terceiro estágio do isolado de Haemonchus contortus, e estes animais foram divididos em dois grupos, controle e tratados, em dependência do tratamento com monepantel. Foram avaliados a redução de ovos nas fezes nos dias $0,2,4,7$ e 14 pós-tratamento e a eficácia terapêutica ao final do período. A redução da contagem de ovos foi observada a partir do $2^{\circ}$ dia pós-tratamento (DPT), com redução máxima, de $32,89 \%$, registrada no $14^{\circ}$ DPT. O teste crítico revelou eficácia de apenas $24,65 \%$, evidenciando resistência ao princípio ativo. A ineficácia do monepantel pode estar associada a utilização do vermífugo de forma massiva, uma vez que o produtor administrava o produto em intervalos inferiores a um mês, sem orientação técnica ou critério definido. Dado que o anti-helmíntico foi usado na propriedade por período inferior a um ano, de acordo com o produtor, pode-se sugerir que Haemonchus contortus desenvolva resistência ao monepantel em poucas gerações caso o produto seja utilizado incorretamente.
\end{abstract}

Palavras-chave: Eficácia. Anti-helmíntico. Derivados da aminoacetonitrila. Ovinos.

\section{Introduction}

The sheep industry sustains frequent economic losses caused by gastrointestinal parasites, especially those resulting from infection by Haemonchus contortus, an important hematophagous parasite of the abomasum of these animals. The damages these parasites cause include impaired growth, reduction in gain weight or weight loss, reduced milk production and, in more severe cases, death. Heavy reliance on the chemical control of this parasite, allied to the constant observation of its resistance to anthelmintics, represents a serious obstacle to production (WALLER, 1997; SANGSTER; GILL, 1999; WOLSTENHOLME et al., 2004; FLEMING et al., 2006; LECOVÁ et al., 2014). An aggravating factor of this situation is the high cost involved in the development of new molecules with anthelmintic activity, which results in low availability of different chemical groups for the treatment of worm infections (PRICHARD, 1994).

A new anthelmintic group, called aminoacetonitrile derivatives (AADS), has recently emerged as a solution for flocks affected by parasites multi-resistant to antiparasitics, a growing problem that affects sheep flocks throughout the planet. The only commercially available representative of this group, monepantel, was first released in New Zealand in 2009 (HOSKING et al., 2010), and reached the Brazilian market in 2012. Several characteristics of this product, such as low toxicity and broad spectrum efficacy against sheep gastrointestinal nematodes, made monepantel an excellent choice for the treatment of sheep flocks (KAMINSKY et al., 2008, 2011).

Although monepantel has been a major breakthrough in the treatment of gastrointestinal helminths in sheep, farms that used this drug as the only treatment option reported that its activity failed after short periods. In New Zealand, three years after the product was launched on the market, resistance of Teladorsagia circumcincta and Trichostrongylus colubriformis to the drug was reported on a sheep and goat breeding farm that had used the dewormer for less than two years (SCOTT et al., 2013). Likewise, Mederos et al. (2014) and Van den Brom et al. (2015) observed early resistance in sheep flocks in Uruguay and the Netherlands, respectively, this time involving Haemonchus contortus.

The aim of this study was to perform controlled studies of fecal egg count reduction (FECRT) and 
critical tests in order to evaluate the effectiveness of monepantel on an isolate of Haemonchus contortus from a sheep farm that had reported failed treatment.

\section{Material and Methods}

\section{Source of the nematodes}

The nematodes used in this study came from the sheep flock of a farm located in the municipality of Taiúva, state of São Paulo, Brazil. The flock consisted of about 100 Santa Inês animals bred in an extensive livestock farming system. The producer used monepantel as the only alternative for helminth control, treating all the animals in a suppressive way, with intervals of less than thirty days between treatments for one year, until the therapeutic failure of the product was suspected.

The pure culture required for the development of the study was established using adult female Haemonchus contortus obtained from the necropsy of two sheep from the farm. The females were placed on Petri dishes with $0.9 \%$ saline and kept in a BOD incubator at $37^{\circ} \mathrm{C}$ and humidity above $80 \%$ for in vitro oviposition. After 48 hours, the resulting eggs were mixed with parasite-free horse feces and wood shavings and subjected to Roberts \& O'Sullivan's method (UENO; GONÇALVES, 1998) to obtain infective larvae. These larvae were then administered to two parasite-free donor animals, which were housed in suspended cages to prevent them from coming into contact with the ground and with their feces. This procedure enabled us to obtain the number of eggs required to infect the animals of the experimental groups.

The larvae needed to inoculate the experimental groups were obtained by coproculture of the feces of the donor animals, and were stored at $6^{\circ} \mathrm{C}$ in a domestic refrigerator for one week.

\section{Formation of the experimental groups}

Twelve 6-month-old Texel x Dorper crossbred sheep, identified by numbered ear tags, were housed in pairs in suspended cages, with ad libitum access to water and a concentrated commercial corn silage diet for sheep. At the beginning of the 1-month period of adaptation, the animals were treated with moxidectin, monepantel, and trichlorfon to eliminate any pre-existing infection, which was confirmed by two negative results on days 15 and 30 of this period.

The twelve animals were orally infected with 5000 infective larvae from the $H$. contortus culture. Fecal tests using the Gordon \& Whitlock method (UENO; GONCALVES, 1998) were performed, starting from the second week post-infection, to determine the beginning of the patent period. After the patent period (32 days), the sheep were divided into experimental groups, based on the average EPG (Eggs Per Gram of feces) on day -1 as the criterion for their paired distribution in five blocks. Within each block, the animals were randomly allocated to the treatment group. After the groups were formed, five animals were treated orally, on day zero (D0) of the experiment, with a dose of $2.5 \mathrm{mgKg}^{-1}$ of monepantel (Zolvix - Novartis Animal Health) purchased locally, following the manufacturer's recommendations, while the animals of the Control group received only distilled water. The drug was administered with a Höppner $50 \mathrm{ml}$ dosing gun with $1 \mathrm{~mL}$ precision, and the dose was estimated based on the weight of each animal, using Filizola MPI-150/4 scales with an adapted box properly calibrated with weights.

Fecal egg count reduction test per gram of feces $E P G$

Fecal samples were collected directly from the rectum of the animals of both experimental groups, thereby preventing possible contamination. The samples were identified with the animal's ear tag number and date of collection. The egg counts were carried out promptly after the feces were collected on days $0,2,4,6,7$ and 14 of the experimental period. 


\section{Critical test}

On day 14 post-infection, all the animals were slaughtered and their abomasum removed after ligation of the ends. Each abomasum was then opened along the larger curvature and washed in running water. All abomasal contents removed by washing were sifted through Tyler 48 mesh metal sieves to concentrate the samples, which were stored in plastic bottles with prewarmed Railliet \& Henry's solution ( $5 \mathrm{~mL}$ formaldehyde, $2 \mathrm{~mL}$ acetic acid, 93 mL 0.9\% saline) (WOOD et al., 1995).

The total parasite load of the abomasal contents was collected using a stereomicroscope and their specific identification was made based on the morphological evaluation of the nematode, which was done as described by Ueno and Gonçalves (1998).

\section{Data analysis}

The results of the egg count reduction tests of animals infected naturally and experimentally were analyzed based on the results of the initial EPG (D0) and final EPG (D14) counts. The EPG count from each group on day zero (initial EPG) was considered for this calculation, i.e., the count of each experimental group before treatment served as control (COLES et al., 1992), as indicated by the following formula:

$\%$ Reduction $=\underline{\text { Mean initial EPG }- \text { Mean final EPG x100 }}$ Mean initial EPG
The arithmetic averages were used to estimate the percent reduction of helminths in each group, using the formula recommended by the Brazilian Ministry of Agriculture, Livestock and Food Supply (BRASIL, 1997) and Vercruysse et al. (2001), as described below. However, to determine the resistant populations, we followed Dobson et al., 2009 and Vercruysse et al., 2002.

Efficacy $(\%)=$ Mean parasitic intensity $(C)-$ Mean parasitic intensity $(T) \times 100$ Mean parasitic intensity $(C)$

Where $\mathrm{C}$ is for Control group, and $\mathrm{T}$ is for treated group.

The log-transformed egg counts and total counts of adults in each of the tests were compared by a simple t-test or the Mann-Whitney test, in dependence of the distribution pattern of the values.

\section{Ethical aspects}

All the procedures carried out in this study were in accordance with current standards of animal welfare and were approved by the Ethics Committee on Animal Use of FCAV, under Protocol no. $013124 / 13$.

\section{Results and Discussion}

The compound monepantel 2.5\% (Zolvix ${ }^{\circledR}$, Novartis Animal Health) reached its maximum therapeutic efficacy of $32.89 \%$ on PTD 14 and a $15.27 \%$ reduction of EPG on PTD 2 (arithmetic average), proving to be resistant according to the criteria established by Coles et al. (1992), and presenting an effectiveness of less than $95 \%$, as described in Table 1. 
Table 1. Individual counts, percent of reduction and of efficacy of the average values of nematode egg counts (strongyles) per gram of feces (EPG) in sheep of the control and treated groups, on post-treatment days (PTD). Arithmetic averages. FCAV/UNESP, Jaboticabal, SP, Brazil. 2015.

\begin{tabular}{|c|c|c|c|c|c|c|c|c|c|}
\hline \multirow{2}{*}{ Animal } & \multirow{2}{*}{ Group } & \multicolumn{8}{|c|}{ Post-Treatment Day } \\
\hline & & D0 & D2 & D4 & D6 & D7 & D9 & D11 & D14 \\
\hline 1 & \multirow{5}{*}{ 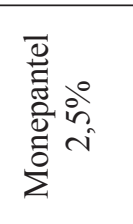 } & 21900 & 12200 & 13600 & 13900 & 16800 & 16900 & 23400 & 17400 \\
\hline 2 & & 9200 & 10100 & 18300 & 12700 & 10500 & 7900 & 13800 & 12100 \\
\hline 3 & & 23800 & 28700 & 17800 & 28200 & 33300 & 42200 & 49200 & 31200 \\
\hline 4 & & 63400 & 48900 & 66400 & 47300 & 39800 & 42400 & 54300 & 39900 \\
\hline 5 & & 7400 & 6600 & 7800 & 12800 & 11300 & 28600 & 26700 & 17600 \\
\hline \multicolumn{2}{|c|}{ MEAN } & $25140^{\mathrm{Aa}}$ & $21300^{\mathrm{Aa}}$ & $24780^{\mathrm{Aa}}$ & $22980^{\mathrm{Aa}}$ & $22340^{\mathrm{Aa}}$ & $27600^{\mathrm{Aa}}$ & $33480^{\mathrm{Aa}}$ & $23640^{\mathrm{Aa}}$ \\
\hline 6 & \multirow{4}{*}{$\begin{array}{l}\text { Do } \\
\text { 节 }\end{array}$} & 19600 & 20100 & 31200 & 30300 & 20600 & 25800 & 33800 & 47100 \\
\hline 8 & & 25200 & 29200 & 28600 & 24500 & 31200 & 48300 & 33900 & 31800 \\
\hline 9 & & 28700 & 14200 & 31500 & 32100 & 18100 & 31800 & 19800 & 18500 \\
\hline 10 & & 42200 & 15900 & 24300 & 28900 & 18600 & 16500 & 21100 & 43500 \\
\hline \multirow{3}{*}{\multicolumn{2}{|c|}{$\begin{array}{l}\text { MEAN } \\
\text { EPG reduction (\%) } \\
\text { Efficacy }(\%)\end{array}$}} & $28925^{\text {Aa }}$ & $19850^{\text {Aa }}$ & $28900^{\text {Aa }}$ & $28950^{\mathrm{Aa}}$ & $22125^{\text {Aa }}$ & $30600^{\text {Aa }}$ & $27150^{\text {Aa }}$ & $35225^{\text {Aa }}$ \\
\hline & & - & 15.27 & 1.43 & 8.59 & 11.14 & O & 0 & 5.97 \\
\hline & & - & 0 & 14.26 & 20.62 & 0 & 9.8 & 0 & 32.89 \\
\hline
\end{tabular}

It is known that mass treatment at short intervals increases selection pressure on anthelmintic resistance, reducing populations of larvae in refuge habitats (SANGSTER; GILL, 1999; VAN WYK, 2001). These factors may have contributed to the rapid emergence of resistance on the farm under study after one year of application of the anthelmintic at 60 day intervals. Mederos et al. (2014) first reported the occurrence in Latin America of Haemonchus resistance to monepantel on two farms in Uruguay. However, those farms were using the drug selectively, one based on fecal egg counts and the other using the Famacha ${ }^{\circledR}$ method, and so after three years of use it failed to reduce the number of eggs in the feces. In both this study and in that of Mederos et al. (2014), the farms used monepantel as the only anthelmintic since its first application. Mederos et al. (2014) observed therapeutic efficacy rates of $0.0 \%$ and $42.0 \%$ with monepantel purchased commercially and from the supplier, respectively, while at another farm observed an $82.1 \%$ efficacy rate. On both farms, the efficacy rate after three years was higher than the rate in this study after one year of use.
The first global report of resistance to monepantel came from New Zealand, with $0 \%$ reduction of eggs in both sheep and goat feces, which was corroborated after conducting confirmatory testing in sheep. In this case, the main helminths involved were Teladorsagia circumcincta and Trichostrongylus colubriformis (SCOTT et al., 2013). Another study reported $0 \%$ efficacy evaluated by the egg reduction test in the feces of a sheep farm in the Netherlands, related to helminths of the genus Haemonchus (VAN DEN BROM et al., 2015).

In the three studies that have reported resistance to monepantel in New Zealand, Uruguay and the Netherlands, this resistance occurred within a period of up to four years after the product was launched on the market (SCOTT et al., 2013; MEDEIROS et al., 2014; VAN DEN BROM et al., 2015), similar to what happened in Brazil. This period is much shorter than what was observed with avermectin, an anthelmintic widely used around the world. Gopal et al. (1999) published the first report of resistance to ivermectin after approximately ten years of use in New Zealand. 
As for the quantification of Haemonchus contortus adults, it was possible to diagnose the therapeutic ineffectiveness of the active ingredient monepantel at a concentration of $2.5 \mathrm{mgKg}^{-1}$ against the aforementioned species, which is the most important one in the sheep industry worldwide. The results of the parasitological necropsies led us to infer a therapeutic efficacy of $24.65 \%$ (arithmetic means), considering the presence of resistance against the compound monepantel $2.5 \%$ based on the higher average counts of Haemonchus contortus specimens present in both groups (Table 2). One of the animals of the control group was removed, since the egg count dropped abruptly starting in the fourth week of the patent period. The necropsy of this animal revealed only 272 helminths, justifying its removal from the study. If this animal had been kept in the study, the efficacy observed for the product would have been $7.31 \%$.

Table 2. Total parasitic intensities of Haemonchus contortus collected from each sheep of the control and treated groups. FCAV/UNESP, Jaboticabal, SP, Brazil. 2015.

\begin{tabular}{cccc}
\hline Animal ID & GI: Control & Animal ID & GII: Monepantel 2.5\% \\
\hline 6 & 19600 & 1 & 3905 \\
7 & $-*$ & 2 & 2565 \\
8 & 3989 & 3 & 2151 \\
9 & 4406 & 4 & 3550 \\
10 & 3847 & 5 & 3602 \\
MEAN & $\mathbf{4 1 8 6 . 2 5}^{\mathbf{A}}$ & & $\mathbf{3 1 5 4 . 6}^{\mathbf{A}}$ \\
Efficacy (\%) & & & $\mathbf{2 4 . 6 5}^{\mathbf{4}}$ \\
\hline
\end{tabular}

* Animal removed from the experiment due to self-cure.

The first case of resistance to monepantel $2.5 \%$ diagnosed through a critical test was reported in sheep from New Zealand, in which the compound appeared to be ineffective, especially against Teladorsagia circumcincta $(0.0 \%)$ and Trichostrongylus colubriformis (9.0\%). Surprisingly, its effectiveness against Oesophagostomum venulosum was also lower than expected, i.e., only 48\%. Moreover, it was also demonstrably ineffective against Capillaria spp, Trichuris spp and Strongyloides spp, although until then there was no record of monepantel activity against these parasites (SCOTT et al., 2013).

Regarding the resistance of Haemonchus contortus in most of the municipalities in the state of São Paulo, this study corroborates the results strength of resistance found in other classes of drugs such as oxfendazole, levamisole, ivermectin and moxidectin (AMARANTE et al., 1992; BUZZULINI et al., 2007).
It is a widely recorded fact that anthelmintics are used extensively on sheep breeding farms. This is recognized as an aggravating factor, which explains the occurrence of resistance in this study, since the farmer reported that such drugs are used continuously in highly frequent treatments at short intervals, which contributes to the selection of resistant populations.

Although most studies demonstrate the high efficacy of monepantel $2.5 \%$ in the egg count reduction test per gram of feces (EPG), we consider it advisable to conduct further studies on other strains using methodologies that include in vivo critical tests, in order to improve accuracy of the results regarding the therapeutic efficacy of monepantel $2.5 \%$ on parasitic worms in sheep. 


\section{Conclusions}

The suspected ineffectiveness of monepantel on the farm of this study was confirmed, and may be ascribed to the massive use of this anthelmintic. Haemonchus contortus proved able to develop resistance to monepantel after a few generations, considering that this anthelmintic had been used on the farm for a period of only one year.

\section{Acknowledgement}

The authors acknowledge CAPES (Brazil's Federal Agency for the Support and Improvement of Higher Education) for its financial support and the scholarships awarded to them.

\section{References}

AMARANTE, A. F. T.; BARBOSA, M. A.; OLIVEIRA, M. A. G.; CARMELLO, M. J.; PADOVANI, C. R. Efeito da administração de oxfendazol, ivermectina e levamizol sobre os exames coproparasitológicos de ovinos. Brazilian Journal of Veterinary Research and Animal Science, São Paulo, v. 29, n. 1, p. 31-38, 1992.

BRASIL. Ministério da Agricultura, Pecuária e Abastecimento. Secretaria de Defesa Agropecuária. Portaria n 48 de 12 de maio de 1997. Diário Oficial [da] União, Brasília, 12 de maio de 1997. Seção 1, n. 92, p. 10165-10169.

BUZZULINI, C.; SILVA-SOBRINHO, A. G.; COSTA, A. J.; SANTOS, T. R.; BORGES, F. A.; SOARES, V. E. Eficácia anti-helmíntica comparativa da associação Albendazol, Levamisole e Ivermectina à Moxidectina em ovinos. Pesquisa Agropecuária Brasileira, Brasília, v. 42, n. 6, p. 891-895, 2007.

COLES, G. C.; BAUER, C.; BORGSTEEDE, F. H. M.; GEERTS, S.; KLEI, T. R.; TAYLOR, M. A.; WALLER, P. J. World Association for the Advancement of Veterinary Parasitology (WAAVP) methods for detection of anthelmintic resistance in nematodes of veterinary importance. Veterinary Parasitology, Amsterdam, v. 44, n. 1-2, p. 35-44, 1992.

DOBSON, R. J.; SANGSTER, N. C.; BESIER, R. B.; WOODGATE, R. G. Geometric means provide a biased efficacy result when conducting a fecal egg count reduction test (FECRT). Veterinary Parasitology, Amsterdam, v. 161, n. 1-2, p. 162-167, 2009.
FLEMING, S. A.; CRAIG, T.; KAPLAN, R. M.; MILLER, J. E.; NAVARRE, C.; RINGS, M. Anthelmintic resistance of gastrointestinal parasites in small ruminants. Journal of Veterinary Internal Medicine, Lawrence, v. 20, n. 2, p. 435-444, 2006.

GOPAL, R. M.; POMROY, W. E.; WEST, D. M. Resistance of field isolates of Trichostrongylus colubriformis and Ostertagia circumcincta to ivermectin. International Journal for Parasitology, Oxford, v. 29, n. 5, p. 781-786, 1999.

HOSKING, B. C.; KAMINSKY, R.; SAGER, H.; ROLFE, P. F.; SEEWALD, W. A Pooled analysis of the efficacy of monepantel, an amino-acetonitrile derivative against gastrointestinal nematodes of sheep. Parasitology Research, Berlin, v. 106, n. 2, p. 529-532, 2010.

KAMINSKY, R.; BAPST, B.; STEIN, P. A.; STREHLAU, G. A.; ALlAN, B. A.; HOSKING, B. C.; ROLFE, P. F.; SAGER, H. Differences in efficacy of monepantel, derquantel and abamectin against multiresistent nematodes of sheep. Parasitology Research, Berlin, v. 109, n. 1, p. 19-23, 2011.

KAMINSKY, R.; DUCRAY, P.; JUNG, M.; CLOVER, R.; RUFENER, L.; BOUVIER, J.; WEBER, S.; WENGER, A.; WIELAND-BERGHAUSEN, S.; GOEBEL, T.; GAUVRY, N.; PAUTRAT, F.; SKRIPSKY, T.; FROELICH, O.; KOMOIN-OKA, C.; WESTLUND, B.; SLUDER, A.; MÄSER, P. A new class of anthelmintics effective against drug-resistant nematodes. Nature, London, v. 452, p. 176-180, 2008.

LECOVÁ, L.; STUCHLÍKOVÁ, L.; PRCHAL, L.; SKÁLOVÁ, L. Monepantel: the most studied new anthelmintic drug of recent years. Parasitology, Cambridge, v. 141, n. 13, p. 1686-1698, 2014.

MEDEROS, A. E.; RAMOS, Z.; BANCHERO, G. E. First report of monepantel Haemonchus contortus resistance on sheep farms in Uruguay. Parasites \& Vectors, Berlin, v. 7, n. 7, p. 598-562, 2014.

PRICHARD, R. Anthelmintic resistance. Veterinary Parasitology, Amsterdam, v. 54, n. 1-3, p. 259-268, 1994.

SANGSTER, N. C.; GILL, J. Pharmacology of anthelmintic resistance. Parasitology Today, Amsterdam, v. 15 , n. 4, p. 141-146, 1999.

SCOTT, I.; POMROY, B.; PAUL, K.; GREG, S.; BARBARA, A.; MOSS, A. Lack of efficacy of monepantel against Teladorsagia circumcincta and Trichostrongylus colubriformis. Veterinary Parasitology, Amsterdam, v. 198, n. 1-2, p. 166-171, 2013. 
UENO, H.; GONÇALVES, P. C. Manual para diagnóstico das helmintoses de ruminantes. 4. ed. Tokio: Japan International Cooperation Agency, 1998. 143 p.

VAN DEN BROM, R.; MOLL, L.; KAPPERT, C.; VELLEMA, P. Haemonchus contortus resistance to monepantel in sheep. Veterinary Parasitology, Amsterdam, v. 209, n. 3-4, p. 278-280, 2015.

VAN WYK, J. A. Refugia - overlooked as perhaps the most potent factor concerning the development of anthelmintic resistance. Onderstepoort Journal of Veterinary Research, Onderstepoort, v. 68, n. 1, p. 55-67, 2001.

VERCRUYSSE, J.; HOLDSWORTH, P.; LETONJA, T.; BARTH, D.; CONDER, G. E.; HAMAMOT, K.; OKANO, $\mathrm{K}$. International harmonisation of Anthelmintic Efficacy Guidelines. Veterinary Parasitology, Amsterdam, v. 96, n. 3, p. 171-193, 2001 .
VERCRUYSSE, J.; HOLDSWORTH, P.; LETONJA, T.; CONDER, G.; HAMAMOTO, K.; OKANO, K.; REHBEIN, S. International harmonisation of anthelmintic efficacy guidelines (Part 2). Veterinary Parasitology, Amsterdam, v. 103, n. 4, p. 277-297, 2002.

WALLER, P. J. Anthelmintic resistance. Veterinary Parasitology, Amsterdam, v. 72, n. 3-4, p. 391-412, 1997.

WOLSTENHOLME, A. J.; FAIRWEATHER, I.; PRICHARD, R.; SAMSON-HIMMELSTJERNA, G.; SANGSTER, N. C. Drug resistance in veterinary helminths. Trends in Parasitology, Oxford, v. 20, n. 10, p. 469-476, 2004.

WOOD, I. B.; AMARAL, N. K.; BAIRDEN, K.; DUNCAN, J. L.; KASSAI, T.; MALONE JÚNIOR, J. B.; PANKAVIC, J. A.; REINECKE, R. K.; SLOCOMBE, O.; TAYLOR, S. M.; VERCRUYSSE, J. World Association for the Advancement of Veterinary Parasitology (W.A.A.V.P.) second edition of guidelines for evaluating the efficacy of anthelmintics in ruminants (bovine, ovine, caprine). Veterinary Parasitology, Amsterdam, v. 58, n. 3, p. 181-213, 1995. 